\title{
SPOUSES' SOCIODEMOGRAPHIC CHARACTERISTICS AND CONTRACEPTIVE USE IN KINSHASA, ZAIRE ${ }^{1}$
}

\section{Djamba Yanyi KASONGO}

\section{Abstract}

This paper examines the impact of spouses' education, fertility desires, and marital characteristics on contraceptive use in Kinshasa, Zaire. The results reveal that, while family planning services focus their activities exclusively on women, husbands' education and fertility desire are very important in explaining the use of birth control in marriage. This male role is crucial in understanding fertility patterns in Africa, where the major familial decisions are made by the husband.

The persistence of high fertility in Africa despite the implementation of family planning has defied both researchers and organizations concerned about the growth of population (Ezeh, 1992). While prior studies attributed low rates of contraceptive use to a lack of information among potential users (Uche, 1972), current data suggest that knowledge is not a determinate factor of birth control (Blanc and Croft, 1992). Instead, in some cases increases in knowledge about and practice of modern contraception have been accompanied by a rise in fertility and natural increase (Dow and Werner, 1981).

As with any other innovation, the success of birth control depends on the identification of social units intervening in decisions on material reproduction, for cultural effects operate through those channels. But as of now there is no agreement about which unit to consider in studies on contraceptive use in Africa, probably because of the theoretical predominance of the Western model of the family.

For some scholars, husband and wife belong to the lineages of their families of origin and should be treated separately (Lesthaeghe, 1989; Marshall, 1970). Others locate the reproductive decision with the dominate spouse's family, away from the biological parents (Caldwell, 1983). We believe, however, that each of these social units 
(husband, wife, and their respective families of origin) has an impact on marital fertility in African societies.

To a certain extent, one's fertility behavior is the result of his own fertility desire controlled for his family's expectations and for the partner's preference. However, given the structure of the African family (Tettekpoe, 1988), marital contraceptive use will depend most on the fertility desire of the dominant spouse.

In this paper we use data from a random sample of married women and married men of child-bearing-age couples in Kinshasa to examine the impact of the wife's and the husband's fertility desires and education, and the influence of their shared characteristics on the practice of birth control. Not ignoring the influence of their families of origin, we limit our current investigation of marital contraceptive use on the impact of spouses' educational attainment and fertility desires, controlling for their marital characteristics. ${ }^{2}$

\section{Background Information}

With a population of about 30 million - and more than 3 million in Kinshasa, the capital city, alone - Zaire does not yet have a population policy. Nonetheless, family planning has been officially adopted and included in the National Health program since 1972. After two decades of birth control in Kinshasa, the percentage of users of modern methods is still very low (7 per cent in 1990; Tambashe and Shapiro, 1991). ${ }^{3}$

Information from surveys on knowledge, attitude, and practice of contraception conducted by birth control services suggests that almost every woman in Kinshasa knows at least one modern method of family planning. For example, in 1985, the percentage of women who had heard of specific methods was for pills, 80 for injection, 68 for tubal ligation, and 65 for condoms. But only five percent of women were using pills, while one percent used injection (Depo Provera) or tubal ligation (PSND, 1986).

Given current levels of total fertility (7 children) and crude death rate (10 per 1000), the population of Kinshasa may reach eight 
million by the year 2000 . It is important to investigate the actual channels of contraceptive use if we are to reduce the growth of population in this city already confronted with a series of social problems (housing, transportation, etc.).

\section{Data and Variables}

This paper is based on data collected through a representative survey of two administrative zones within the city limits of Kinshasa, the most populous city in Zaire (Zaïre, 1984). Within each zone, households in four quarters ${ }^{4}$ were identified, and, within these, a random sample of married men and women was selected and interviewed in April-May 1991. The sample is therefore representative of households occupied in the two zones during 1991.

Although not strictly representative of all areas in Kinshasa, the two administrative zones that were chosen covered two principal areas of the city and different economic bases. Lemba is an older section of the city where the majority of the literate in Kinshasa reside. It contains the University of Kinshasa, which is the largest university in Zaire, and thus houses many of the university's students, staff, and faculty. In contrast, Ngaba is an area of city known as the urban ghetto. The majority of the population there originated in Bandundu, one of the closest provinces to Kinshasa. Residents from Bandundu move to Ngaba in search of employment and economic opportunities.

Although we sought to interview both spouses in these households, a pretest of the survey revealed that most persons were unlikely to participate if their spouses had been interviewed earlier. Thus, only one person in each household was sampled, for a total of 507 married men and 515 married women. The survey questionnaire collected the social, economic, and demographic characteristics of spouses, including information on marital and sexual history, fertility, and contraception. Since respondents are from the same population of married people, and given the similarity in the distribution of responses given by women and men for the variables used in the current analysis, the two subsamples were combined. Thus the size of the global sample is 1022 couples. $^{5}$ 
For the present paper, two dependent variables and nine explanatory variables are used. The dependent variables are the current use (of any type) of contraception noted Any Method, and the current use of a modern method labeled Modern. The second dependent variable, Modern, refers to the use of a modern method of contraception at the moment of the survey. This category includes pills, sterilization, injection, diaphragms, condoms, and tubal ligation. The first dependent variable, Any Method, includes the use of either one of the modern methods mentioned above, or a traditional method which can be abstinence, withdrawal, or other means of birth control.

There are two types of independent variables: spouses' education and fertility desires, and their conjugal or shared attributes. The last group includes age difference between spouses, type of union, duration of union, spouses' previous marital status, and communication.

Unlike other independent variables that are categorical, communication between spouses is computed from four questions on whether or not spouses discuss 1) birth control, 2) number of children, 3 ) choice of housing, and 4) education of children. A positive answer to each of these questions was coded 1 , and a negative response 0 . Hence, for the four questions the maximum score for each couple is 4 and the minimum 0 .

Previous studies showed that wife's education has strong net positive effects on contraceptive use (Tambashe and Shapiro, 1991; Wamucii, 1990). What is not known, however, is the effects of husband's characteristics on marital contraceptive use. Do wives' education and fertility desires determine more than husbands' the likelihood of contraceptive use in marriage?

\section{Characteristics of Couples}

Table 1 shows that, in general, men in the sample were more educated than their wives. Only eight per cent of wives had a college education, compared to 39 per cent of the husbands. This educational gap may explain the lower position of women within the marriage. However, fertility desires were almost equally distributed; 63 per cent 
of the wives and 64 per cent of the husbands wanted to have children. Such a pronatalist attitude may account for the low rate of modern contraceptive use.

There was a noticeable age gap between husbands and wives. Overall, men are older than their wives; in most of the couples, husbands are 5 to 9 years older than their wives. The distribution of couples by type of union indicates that the large majority of unions are monogamous; only nine per cent of marriages are polygamous.

Although data used here are not from a longitudinal observation, the distribution of couples by duration of marriage shows that most unions have lasted for more than nine years. Since the majority of the spouses are in their first marriage ( 80 per cent), one may conclude that marriage is quite stable in Kinshasa and that there is a delay of union formation among younger generations. These differences in terms of education and age are crucial to the adoption of birth control, because they might influence conjugal relationships and fertility desires of spouses.

\section{Prevalence of Contraceptive Use}

Table 2 shows that 71 per cent of couples were using some type of contraceptive, but only 15 per cent used a modern method. In other words, only one in four user couples was using a modern method. One finding of this study is that contraceptive use increases with both women's and men's levels of education. Also, their fertility desires have an impact on the practice of birth control. For both women and men, the desire to have children is negatively associated with the use of contraceptive methods.

The distribution of couples by age difference between husband and wife indicates that the closer spouses' age, the higher the likelihood of contraceptive use. This relation seems stronger for Modern contraception than for Any Method. In contrast, there is no important difference in contraceptive use between monogamous and polygamous unions. It is probable, however, that polygamous unions practiced more traditional methods than monogamous ones. 
Because of the positive link between duration of marriage and fertility couples who have been married for ten years and more have the highest rate of modern contraceptive use. New couples practice mostly traditional methods (Any Method). With respect to previous marital status, couples in which both spouses are in their first marriage (previously single) practice birth control more than those with one or two previously married partners.

\section{Net Effects of Independent Variables on Contraceptive Use}

To determine the real contribution of each of the variables discussed above, we used logistic regression procedures; the results are presented in Tables 3 and 4 . The dependent variables are dichotomous, indicating whether or not the couple was using contraception at the moment of the survey. Table 3 displays the results for the use of contraception in general (Any Method). Table 4 gives the estimates for modern contraceptive use. For each dependent variables seven models are constructed in order to examine the net effect of the explanatory variables.

The first Model in Table 3 is the traditional approach in which only wife's education is considered. This equation shows the net effect of women's education on contraceptive use. The second equation (Model 2) considers only husband's education. In each of these first two Models, education is an important factor of contraceptive use. Yet, it might be misleading to emphasize the effect of one partner's education. This caution is clearly reflected in the third Model where both wife's and husband's education are introduced in the equation; the wife's education does not stand before the husband's.

In fact, when spouses' educational effects are controlled for wife's fertility desire (Model 4), the probability of contraceptive use associated with both partners' education becomes significant, but more for the husband's. Couples in which wives have a secondary level of education and husbands university level are more likely to use contraception (Any Method) than couples who have other levels of education. This pattern suggests the effect of current fertility on contraceptive use. The same trend appears in Model 5 where husband's fertility desire is added to both spouses' education. 
Does all this mean that the wife's and the husband's fertility desires are equally important in explaining contraceptive use? If this were the case, then Model 6, in which both spouses' fertility desires are controlled, would generate equal or at least similar coefficients for the two individual variables. Rather, it is shown that husband's desire is not only significant, but also accounts for more than twice as much as the wife's preference does in the regression equation of marital contraceptive use.

Even after controlling for spouses' shared and conjugal characteristics (Model 7), husband's education and fertility remain significant. But taken altogether, previous marital status and communication between spouses are the most important predictors of contraceptive use. Couples in which both spouses are at their first marriage, and those holding discussion on marital and familial matters, are more likely to use birth control. There is no significant relationship between either type of union or age difference between spouses and contraceptive use.

Turning now to modern contraceptive use (Table 4), spouses' education are the strongest variables across all Models. But combined in the same equation, husband's education is more important than wife's. The situation for fertility desires is similar to that found in Table 3, except that none of the spouses' desire is significant in Model 7. Another important finding in Table 4 is that, unlike Any Method, couples in which wives have university level are more likely to use contraception than those where wives are less educated. Equally important are the age difference between spouses, the duration of marriage, and communication between wife and husband.

The larger the age difference between husband and wife, the less likely the couple is to use modern methods of birth control. This age gap is to some extent an index of closeness in conjugal relationships. As for Any Method, the type of marriage has no significant effect on modern contraceptive use. The positive significant coefficient associated with duration of marriage indicates that spouses are more likely to practice modern contraception when they already have the desired number of children. In either case, communication remains important in predicting the likelihood of marital contraceptive use. 


\section{Summary and Conclusion}

Prior studies on contraception tended to concentrate on the characteristics of women that influence the probability of the use of birth control. Today researchers question the relevance of such an approach given the subordinate role played by wives in Africa (Djamba, 1991; 1990). Thus, indeed men know more about family planning than do their wives' fertility desire (Ezeh, 1992).

This explanatory analysis suggests that the use of effective methods of contraception depends on both the wife's and the husband's education, but more on the husband's. For both modern and traditional methods, the level of communication is an important factor in the adoption of birth control. Due to the pronatalist attitude of individuals in Kinshasa, it is rational that traditional methods be used mostly among couples who have been married for five to nine years, and that modern contraception be used generally beyond nine years of marital life. This delay in modern contraceptive use is probably the result of the fertility goals of individuals in Kinshasa, where the desired number of children is still high ( 5 according to our data).

It was also found that the type of marriage has no significant effect on birth control. In contrast, the previous marital status of spouses is significant in predicting their practice of birth control. Couples in which both spouses are in their first marriage are more likely to use contraception than those with one or two remarried spouses.

Another problem that restrains couples from effective methods of family planning is the belief that a woman may cheat on her husband if she is (fully) protected from unwanted pregnancies. On the other hand, marital reproduction is not the sole responsibility of the nuclear family; as marriage itself involves the consensus of spouses' families of origin, so too does marital fertility (Caldwell and Caldwell, 1987).

Despite all these constraints surrounding marital fertility, husbands can successfully initiate the control of fertility. They might use their social status to introduce and make their wives adopt family planning. Even when social norms consider large family as a model, men with their breadwinner role are capable of changing the familial reproductive behavior according to their own desires. 
Table 1: Distribution of Couples by Spouses' Education and Fertility Desires, and by Nuptial Characteristics

\begin{tabular}{|c|c|c|c|}
\hline & Variable name and definition & $\mathbf{N}$ & 8 \\
\hline $\begin{array}{l}\text { WIFEDUC } \\
\text { PRIMLESS } \\
\text { SEC } \\
\text { UNIV }\end{array}$ & $\begin{array}{l}\text { Wife's Education } \\
\text { Primary or none } \\
\text { Secondary } \\
\text { Univergity }\end{array}$ & $\begin{array}{r}290 \\
542 \\
76\end{array}$ & $\begin{array}{r}32 \\
60 \\
8\end{array}$ \\
\hline $\begin{array}{l}\text { HUSBEDUC } \\
\text { PRIM } \\
\text { SEC } \\
\text { UNIV } \\
\end{array}$ & $\begin{array}{l}\text { Husband's Education } \\
\text { Primary } \\
\text { Secondary } \\
\text { Univergity }\end{array}$ & $\begin{array}{l}156 \\
400 \\
352\end{array}$ & $\begin{array}{l}17 \\
44 \\
39\end{array}$ \\
\hline $\begin{array}{l}\text { WIFEFERD } \\
\text { WANTS } \\
\text { DONTW } \\
\end{array}$ & $\begin{array}{l}\text { Wife's Fertility Desire } \\
\text { Wants to have child(ren) } \\
\text { Wants no more }\end{array}$ & $\begin{array}{l}570 \\
338\end{array}$ & $\begin{array}{l}63 \\
37\end{array}$ \\
\hline $\begin{array}{l}\text { HUSBFERD } \\
\text { WANTS } \\
\text { DONTW } \\
\end{array}$ & $\begin{array}{l}\text { Husband's Fertility Desire } \\
\text { Wants to have child(ren) } \\
\text { wants no more }\end{array}$ & $\begin{array}{l}586 \\
322\end{array}$ & $\begin{array}{l}64 \\
36\end{array}$ \\
\hline $\begin{array}{l}\text { AGED } \\
\text { LT5 } \\
5-9 \\
10+ \\
\end{array}$ & $\begin{array}{l}\text { Age Difference Between spouses (2) } \\
\text { Less than five years } \\
\text { Five to nine years } \\
\text { Ten years or more }\end{array}$ & $\begin{array}{l}190 \\
367 \\
296\end{array}$ & $\begin{array}{l}22 \\
43 \\
35\end{array}$ \\
\hline $\begin{array}{l}\text { TYPUN } \\
\text { MONO } \\
\text { POLY }\end{array}$ & $\begin{array}{l}\text { Type of union } \\
\text { Monogomous } \\
\text { Polygamous }\end{array}$ & $\begin{array}{r}829 \\
79\end{array}$ & $\begin{array}{r}91 \\
9\end{array}$ \\
\hline $\begin{array}{l}\text { DURUN } \\
0-4 \\
5-9 \\
10+ \\
\end{array}$ & $\begin{array}{l}\text { Duration of union }(2) \\
\text { zero to four years } \\
\text { Five to nine years } \\
\text { Ten years or more }\end{array}$ & $\begin{array}{l}206 \\
225 \\
474\end{array}$ & $\begin{array}{l}23 \\
25 \\
52\end{array}$ \\
\hline $\begin{array}{l}\text { PREMAR } \\
\text { BOTHM } \\
\text { ONEM } \\
\text { BOTHS } \\
\end{array}$ & $\begin{array}{l}\text { Previous marital status } \\
\text { Both married } \\
\text { One spouse married } \\
\text { Both single }\end{array}$ & $\begin{array}{r}49 \\
135 \\
724\end{array}$ & $\begin{array}{r}5 \\
15 \\
80\end{array}$ \\
\hline TOTAL & & 908 & 100 \\
\hline
\end{tabular}

Note: 1. For women, "PRIMLESS" includes also four per cent of uneducated wives.

2. Total observations (N) for these variables are less than 908 due to missing data. 
Table 2: Percentage Distribution of Couples Using Contraception Within Each Category of Independent Variables

\begin{tabular}{|c|c|c|c|}
\hline & Variable name and definition & $\mathbf{N}$ & 8 \\
\hline $\begin{array}{l}\text { WIFEDUC } \\
\text { PRIMLESS } \\
\text { SEC } \\
\text { UNIV }\end{array}$ & $\begin{array}{l}\text { Wife's Education } \\
\text { Primary or none } \\
\text { Secondary } \\
\text { University }\end{array}$ & $\begin{array}{l}65 \\
73 \\
78\end{array}$ & $\begin{array}{l}13 \\
15 \\
22\end{array}$ \\
\hline $\begin{array}{l}\text { HUSBEDUC } \\
\text { PRIM } \\
\text { SEC } \\
\text { UNIV } \\
\end{array}$ & $\begin{array}{l}\text { Husband's Education } \\
\text { Primary } \\
\text { Secondary } \\
\text { University }\end{array}$ & $\begin{array}{l}64 \\
68 \\
78\end{array}$ & $\begin{array}{l}10 \\
14 \\
19\end{array}$ \\
\hline $\begin{array}{l}\text { WIFEFERD } \\
\text { WANTS } \\
\text { DONTW }\end{array}$ & $\begin{array}{l}\text { Wife's Fertility Desire } \\
\text { Wants to have child(ren) } \\
\text { Wants no more }\end{array}$ & $\begin{array}{l}70 \\
73\end{array}$ & $\begin{array}{l}13 \\
18\end{array}$ \\
\hline $\begin{array}{l}\text { HUSBFERD } \\
\text { WANTS } \\
\text { DONTW }\end{array}$ & $\begin{array}{l}\text { Husband's Fertility Desire } \\
\text { Wants to have child(ren) } \\
\text { Wants no more }\end{array}$ & $\begin{array}{l}69 \\
74\end{array}$ & $\begin{array}{l}13 \\
18\end{array}$ \\
\hline $\begin{array}{l}\text { AGED } \\
\text { LT5 } \\
5-9 \\
10+ \\
\end{array}$ & $\begin{array}{l}\text { Age Difference Between spouses } \\
\text { Less than five years } \\
\text { Five to nine years } \\
\text { Ten years or more }\end{array}$ & $\begin{array}{l}74 \\
72 \\
71\end{array}$ & $\begin{array}{l}20 \\
15 \\
13\end{array}$ \\
\hline $\begin{array}{l}\text { TYPUN } \\
\text { MONO } \\
\text { POLY }\end{array}$ & $\begin{array}{l}\text { Type of union } \\
\text { Monogomous } \\
\text { Polygamous }\end{array}$ & $\begin{array}{l}71 \\
75\end{array}$ & $\begin{array}{l}15 \\
16\end{array}$ \\
\hline $\begin{array}{l}\text { DURUN } \\
0-4 \\
5-9 \\
10+ \\
\end{array}$ & $\begin{array}{l}\text { Duration of union } \\
\text { zero to four years } \\
\text { Five to nine years } \\
\text { Ten years or more }\end{array}$ & $\begin{array}{l}70 \\
78 \\
68\end{array}$ & $\begin{array}{l}13 \\
12 \\
18\end{array}$ \\
\hline $\begin{array}{l}\text { PREMAR } \\
\text { BOTHM } \\
\text { ONEM } \\
\text { BOTHS } \\
\end{array}$ & $\begin{array}{l}\text { Previous marital status } \\
\text { Both married } \\
\text { One spouse married } \\
\text { Both single }\end{array}$ & $\begin{array}{l}65 \\
70 \\
72\end{array}$ & $\begin{array}{l}10 \\
15 \\
16\end{array}$ \\
\hline $\begin{array}{l}\text { ALL } \\
\text { COUPLES }\end{array}$ & & 71 & 15 \\
\hline
\end{tabular}


Table 3: Logistic Regression Resulta Predicting the Likelihood of Marital Contraceptive Use (Any Method)

\begin{tabular}{|c|c|c|c|c|c|c|c|}
\hline \multirow[t]{2}{*}{ Variable } & \multicolumn{7}{|c|}{ Model } \\
\hline & 1 & 2 & 3 & 4 & 5 & 6 & 7 \\
\hline $\begin{array}{l}\text { WIFEDUC } \\
\text { PRIMLESS } \\
\text { SEC } \\
\text { UNIV }\end{array}$ & $\begin{array}{c}- \\
.215 * * \\
.428 * * \\
\end{array}$ & & $\begin{array}{l}- \\
.124 \\
.121\end{array}$ & $\begin{array}{l}- \\
.188 * \\
.213\end{array}$ & $\begin{array}{l}- \\
.186 * \\
.209 \\
\end{array}$ & $\begin{array}{c}- \\
.188 * \\
-213 \\
\end{array}$ & $\begin{array}{c}- \\
.005 \\
-.125\end{array}$ \\
\hline $\begin{array}{l}\text { HUSBEDUC } \\
\text { PRIM } \\
\text { SEC } \\
\text { UNIV } \\
\end{array}$ & & $\begin{array}{c}- \\
-.104 \\
.418^{* * 4}\end{array}$ & $\begin{array}{c}- \\
-.152 \\
.344^{* *}\end{array}$ & $\begin{array}{l}- \\
-.128 \\
.364^{* *}\end{array}$ & $\begin{array}{c}- \\
-.130 \\
.356^{* *}\end{array}$ & $\begin{array}{c}- \\
. .128 \\
.364 * *\end{array}$ & $\begin{array}{c}- \\
-.111 \\
-289 *\end{array}$ \\
\hline $\begin{array}{l}\text { WIFEFERD } \\
\text { WANTS } \\
\text { DONTW }\end{array}$ & & & & $.210^{*}$ & & .108 &.$\overline{-}$ \\
\hline $\begin{array}{l}\text { HUSBFERD } \\
\text { WANTS } \\
\text { DONTW } \\
\end{array}$ & & & & & $.288 * *$ & $.210^{*}$ & $.236^{*}$ \\
\hline $\begin{array}{l}\text { AGED } \\
\text { LT5 } \\
5-9 \\
10+ \\
\end{array}$ & & & & & & & $\begin{array}{r}- \\
-.089 \\
.048 \\
\end{array}$ \\
\hline $\begin{array}{l}\text { TYPUN } \\
\text { MONO } \\
\text { POLY } \\
\end{array}$ & & & & & & & .236 \\
\hline $\begin{array}{l}\text { DURUN } \\
0-4 \\
5-9 \\
10+\end{array}$ & & & & & & & $\begin{array}{r}- \\
.335 * * \\
-.349 * * *\end{array}$ \\
\hline $\begin{array}{l}\text { REMAR } \\
\text { BOTHM } \\
\text { ONEM } \\
\text { BOTHS } \\
\end{array}$ & & & & & & & $\begin{array}{c}- \\
.416^{*} \\
.666^{4+4} \\
\end{array}$ \\
\hline COMMUNICATION & & & & & & & $.471^{* * * *}$ \\
\hline $\begin{array}{l}\text { CONSTANT } \\
\text { LOG- } \\
\text { LIKELIHOOD }\end{array}$ & $\begin{array}{c}.985 \\
.2432 .7\end{array}$ & $\begin{array}{c}.940 \\
.2415 .8\end{array}$ & $\begin{array}{c}.948 \\
-2414.6\end{array}$ & $\begin{array}{c}.999 \\
-2408.8\end{array}$ & $\begin{array}{c}.996 \\
-2407.5\end{array}$ & $\begin{array}{c}.999 \\
-2407.0\end{array}$ & $\begin{array}{l}-.578 \\
-2292.4\end{array}$ \\
\hline
\end{tabular}

$* \mathbf{P}<.05, * * \mathbf{P}<.01 ; * * \mathbf{P}<.001$. 
Table 4: Logistic Regression Results Predicting the Likelihood of Marital Contraceptive Use (Modern Method)

\begin{tabular}{|c|c|c|c|c|c|c|c|}
\hline \multirow[t]{2}{*}{ Variable } & \multicolumn{7}{|c|}{ Model } \\
\hline & 1 & 2 & 3 & 4 & 5 & 6 & 7 \\
\hline $\begin{array}{l}\text { WIFEDUC } \\
\text { PRIMLESS } \\
\text { SEC } \\
\text { UNIV }\end{array}$ & $\begin{array}{c}- \\
.081 \\
.617^{+* * *} \\
\end{array}$ & & $\begin{array}{r}- \\
-.076 \\
.295+\end{array}$ & $\begin{array}{r}- \\
. .010 \\
.395 *\end{array}$ & $\begin{array}{c}. \\
.003 \\
.404^{*}\end{array}$ & $\begin{array}{c}- \\
.009 \\
.418^{*}\end{array}$ & $\begin{array}{c}- \\
.001 \\
.383 *\end{array}$ \\
\hline $\begin{array}{l}\text { HUSBEDUC } \\
\text { PRIM } \\
\text { SEC } \\
\text { UNIV } \\
\end{array}$ & & $\begin{array}{c}- \\
.108 \\
.549+* *\end{array}$ & $\begin{array}{c}- \\
.136 \\
.526^{* * *}\end{array}$ & $\begin{array}{c}. \\
.164 \\
.565 *+* \\
\end{array}$ & $\begin{array}{c}- \\
.165 \\
.542^{2+*}\end{array}$ & $\begin{array}{c}- \\
.168 \\
.558^{*+*}\end{array}$ & $\begin{array}{c}- \\
.163 \\
.542^{* 0}\end{array}$ \\
\hline $\begin{array}{l}\text { WIFEFERD } \\
\text { WANTS } \\
\text { DONTW }\end{array}$ & & & & $.362^{-}$ & & $.231+$ & .025 \\
\hline $\begin{array}{l}\text { HUSBFERD } \\
\text { WANTS } \\
\text { DONTW }\end{array}$ & & & & & $\stackrel{-}{-351^{+* *}}$ & $.185+$ &. \\
\hline $\begin{array}{l}\text { AGED } \\
\text { LT5 } \\
5-9 \\
10+\end{array}$ & & & & & - & & $\begin{array}{l}- \\
-.295 * * \\
-.320 * *\end{array}$ \\
\hline $\begin{array}{l}\text { TYPUN } \\
\text { MONO } \\
\text { POLY }\end{array}$ & & & & & & & $\begin{array}{c}- \\
.065\end{array}$ \\
\hline $\begin{array}{l}\text { DURUN } \\
0-4 \\
5-9 \\
10+\end{array}$ & & & & & & & $\begin{array}{c}- \\
-.178 \\
.370^{* 4}\end{array}$ \\
\hline $\begin{array}{l}\text { REMAR } \\
\text { BOTHM } \\
\text { ONEM } \\
\text { BOTHS }\end{array}$ & & & & & & & $\begin{array}{c}. \\
.247 \\
.369+\end{array}$ \\
\hline COMMUNICATION & & & & & & & $.334^{* * *}$ \\
\hline $\begin{array}{l}\text { CONSTANT } \\
\text { LOG- } \\
\text { LIKELIHOOD }\end{array}$ & $\begin{array}{l}-1.618 \\
-1716.0\end{array}$ & $\begin{array}{l}-1.800 \\
-1709.6\end{array}$ & $\begin{array}{l}-1.710 \\
-1706.6\end{array}$ & $\begin{array}{l}-1.670 \\
-1699.1\end{array}$ & $\begin{array}{l}-1.665 \\
-1699.6\end{array}$ & $\begin{array}{l}-1.660 \\
-1698.1\end{array}$ & $\begin{array}{l}-3.044 \\
-1661.3\end{array}$ \\
\hline
\end{tabular}

$+\mathrm{P}<.05, * * \mathrm{P}<.01 ; * *+\mathrm{P}<.001$. 


\section{Notes}

1. This research received support from the Special Programme of Research, Development and Research Training in Human Reproduction, World Health Organization. The author is grateful to Professor Joachim. Singlemann and to the anonymous reviewer for their useful comments and suggestions.

2. This paper is based on the preliminary results of ongoing research on Spouses' Differentials Roles in Control of Fertility in Kinshasa.

3. Tambashe and Shapiro considered both married and unmarried women. Therefore, the seven per cent of users found in their study does not represent the prevalence of marital contraceptive use.

4.

A quartier is the smallest administrative residential unit in Kinshasa.

5. Due to missing values, the effective sample falls short below this number. 


\section{References}

Blanc, A.K. and Croft, N.T. (1992). "The Effect of the Sex of the Interviewer on Responses in Fertility Surveys: the Case of Ghana." Paper presented at the Annual Meeting of the Population Association of America, April 30-May 2, 1992, Denver, Colorado.

Caldwell, J.C. and Caldwell, P. (1987). "The Cultural Context of High Fertility in Sub-Saharan Africa," Population and Development Review 13(3): 409-437.

Caldwell, J.C. (1983). "Direct Economic Costs and Benefits of Children." In Bulatao, A.R. and Lee, D.R., eds., Determinants of Fertility in Developing Countries, Vol.1. New York: Academic Press.

Djamba, Y.K. (1991). "Note méthodologique pour la recherche du rôle des époux dans la planification familiale en Afrique," Etude de la population africaine 5 .

Djamba, Y.K. (1990). "Rôle différentiel des époux dans la planification familiale en Afrique: Recherche méthodologique." Cahiers économiques et sociaux 24(1-2).

Dow, T.E. Jr., and Werner, H.L. (1981). "Family size and population in Kenya: Continuity and change in metropolitan and rural attitudes," Studies in Familv Planning 12(6/7): 272277.

Ezeh, A.C. (1992). "Contraceptive Practice in Ghana: Does Partner's Attitude Matter?" Paper presented at the Annual Meeting of the Population Association of America, April 30-May 2, Denver, Colorado.

Lesthaeghe, R. (1989). "Social Organization, Economic Crisis and the Future of Fertility Control in Africa." In Lesthaeghe, R., ed., Reproduction and Social Organization in Sub-Saharan Africa. Chapel Hill: University of North Carolina Press. 
Marshaill, G. (1970). "In a world of women: Field work in the Yoruba community." In Golde, P., ed., Women in the Field: Anthropological Experiences. Chicago: Aldine.

PSND (1986). "Naissances désirables et le Centre de Libota Lilamu: Connaissances et utilisation par la population féminine de la Zone de Kintambo," Séries de recherche PSND 1.

Tambashe, O. and Shapiro, D. (1991). Employment. Education, and Fertility Behavior: Evidence from Kinshasa. Kinshasa: Université de Kinshasa.

Tettekpoe, D. (1988). "Environnement socio-culturel et planification en Afrique." In Actes du colloque sur: Information. éducation. communications et planification en Afrique. Dakar: UEPA.

Uche, C. (1972). "Population Problems and Family Planning in Africa," Sociologia Ruralis 12(3-4): 419-430.

Wamucii, N. (1991). "Trends and Determinants of Contraceptive Use in Kenya," Demography 28(1): 83-97.

Zaïre, Rép. du (1988). Combien sommes-nous ? Récensement scientifique de la population de 1984 : Résultats provisoires. Kinshasa: Institut national de la statistique. 